\title{
UANG DALAM PERSPEKTIF EKONOMI ISLAM ${ }^{*}$
}

\author{
Takiddin ${ }^{1}$ \\ Permalink: https://www.academia.edu/9997589
}

\begin{abstract}
Money in the Islamic Economic Perspectives. This article aims at giving description about money in the perspective of Islamic economic. The data gathered through library research. Islamic economic system is different from economic system with the basis of socialism, capitalism, mix economic, communism, and traditional; one of the differences is on its perspective towards money. The function of money in Islamic economic perspectives is that it functions as a medium of exchange for goods and services. Islam forbids stacking money and making money as a commodity. Because stacking money slows down the velocity of money. It gives impact on minimizing financial transaction and resulting to the economic decrease. Islam proscribes interest and refuses all pseudo-transactions as happen in money market and capital market.
\end{abstract}

Keywords: money, Islamic economics

Abstrak: Uang Dalam Persfektif Ekonomi Islam. Artikel ini ditulis untuk memberikan gambaran tentang uang dalam perspektif ekonomi Islam. Guna memperoleh data yang dimaksud, penulis melakukan kajian kepustakaan. Sistem Ekonomi Islam berbeda dengan sistem ekonomi kapitalisme, sosialisme, ekonomi campuran, komunisme dan sistem ekonomi tradisional. Salah satu perbedaannya adalah pandangan terhadap fungsi uang. Fungsi uang dalam perspektif ekonomi Islam hanya terbatas pada uang sebagai alat tukar barang dan jasa. Islam melarang penumpukan uang dan menjadikan uang sebagai sebuah komoditas. Karena penimbunan uang berarti memperlambat perputaran uang. Hal ini berarti memperkecil terjadinya transaksi, sehingga perekonomian menjadi lesu. Islam mengharamkan riba dan menolak segala jenis transaksi semu seperti yang terjadi di pasar uang atau pasar modal saat ini.

Kata Kunci: Uang, Ekonomi Islam

* Diterima tanggal naskah diterima: 14 Juni 2014, direvisi: 25 Oktober 2014, disetujui untuk terbit: 14 November 2014.

${ }^{1}$ Fakultas Ilmu Tarbiyah dan Keguruan (FITK) UIN Jakarta. Jl. Ir. H. Juanda No. 95 Ciputat. Email:Takiddin@gmail.com. 


\section{Pendahuluan}

Dengan melakukan penelaahan induktif terhadap hukum-hukum syara' yang menyangkut masalah ekonomi, diketahui bahwa Sistem Ekonomi Islam berbeda dengan sistem ekonomi lainnya, seperti kapitalisme, sosialisme, ekonomi campuran, komunisme dan sistem ekonomi tradisional. Perbedaan itu terdapat dalam berbagai aspek. Salah satu diantaranya adalah perbedaan pandangan terhadap fungsi uang. Uang merupakan inovasi besar dalam peradaban perekonomian dunia, posisinya sangat strategis dalam sistem ekonomi, dan sulit untuk diganti dengan media lainnya. Sepanjang sejarah keberadaannya, uang memainkan peran penting dalam perjalanan kehidupan manusia. Uang berhasil memudahkan dan mempersingkat waktu transaksi pertukaran barang dan jasa. Uang dalam sistem ekonomi memungkinkan perdagangan berjalan secara efektif dan efisien. Keberadaan uang menyediakan alternatif transaksi yang lebih mudah daripada barter yang lebih kompleks, tidak efisien, dan kurang cocok digunakan dalam sistem ekonomi modern karena membutuhkan orang yang memiliki keinginan yang sama untuk melakukan pertukaran dan juga kesulitan dalam penentuan nilai. ${ }^{2}$ Efisiensi yang didapatkan dengan menggunakan uang pada akhirnya akan mendorong perdagangan dan pembagian tenaga kerja yang kemudian akan meningkatkan produktifitas dan kemakmuran.

Pada awalnya fungsi uang masih pada fungsi utamanya yaitu sebagai alat tukar. Namun dalam perkembangannya fungsi utama itu mulai mengalami pergeseran. Sistem ekonomi kapitalis memandang fungsi uang tidak hanya sebagai alat tukar, tetapi juga dijadikan sebagai sebuah komoditas, sehingga uang bisa diperjualbelikan layaknya sebagai suatu komoditas. Sedang dalam konsep keuangan modern yang diajarkan oleh kaum Kapitalis dan Sosialis, uang menjadi obyek perdagangan.

Perdagangan uang merupakan instrumen penting dalam sistem perekonomian. Inilah yang menjadi perdebatan dalam sistem ekonomi Islam, apa fungsi uang yang sesungguhnya. Apakah uang hanya berfungsi sebagai alat tukar sebagaimana fungsi uang pada masa awalnya ataukah uang bisa dianggap sebagai sebuah komoditas yang bisa diperjualbelikan. Tulisan ini akan membahas mengenai fungsi uang dalam persepektif ekonomi Islam.

\section{Pengertian Uang}

Sebelum membahas mengenai pandangan Islam terhadap uang, terlebih dahulu dikemukakan pengertian uang. Uang dalam ilmu ekonomi tradisional didefinisikan sebagai setiap alat tukar yang dapat diterima secara umum. Alat tukar itu dapat berupa benda apapun yang dapat diterima oleh setiap orang di masyarakat dalam proses pertukaran barang dan jasa. Dalam ilmu ekonomi modern, uang didefinisikan sebagai sesuatu yang tersedia dan secara umum diterima sebagai alat pembayaran bagi pembelian barang-barang dan jasa-jasa serta kekayaan berharga lainnya serta untuk pembayaran hutang.

${ }^{2}$ Wikipedia, Uang, [online], (tersedia): (http://id.wikipedia.org), 2014. 
Beberapa ahli juga menyebutkan fungsi uang sebagai alat penunda pembayaran. $^{3}$

Uang dalam Islam pada mulanya dicerminkan dalam dirham sebagai alat tukar dan alat nilai, kemudian berkembang menjadi uang emas dan perak dengan nama dinar (negara Arab). Uang dan fungsinya sebagai alat tukar dan alat nilai dikemukakan juga oleh Ibn Khaldun dan al-Ghazali. ${ }^{4}$

\section{Dinar dan Dirham dalam Ekonomi Islam}

Mata uang yang direkomendasikan dalam Ekonomi Islam adalah dinar (Emas) dan dirham (Perak). Dinar emas adalah koin emas berkadar 22 karat $(91,70 \%)$ dengan berat 4,25 gram. Sedangkan Dirham perak adalah koin perak murni (99.95\%) dengan berat 2.975 gram. Standar Dinar dan Dirham ini telah ditetapkan oleh Rasulullah SAW, pada tahun 1 Hijriyah, dan kemudian ditegakkan oleh Khalifah Umar ibn Khattab pada tahun 18 Hijriyah. Pada saat itu untuk pertama kalinya Khalifah Umar ibn Khattab mencetak koin Dirham. Sedangkan orang yang pertama kali mencetak Dinar emas Islam adalah Khalifah Malik ibn Marwan pada tahun 70 Hijriah, dengan tetap mengacu kepada ketentuan dari Rasulullah Saw. maupun Umar ibn Khattab ra., yaitu dalam rasio berat 7/10 (7 Dinar berbanding 10 Dirham). ${ }^{5}$

Bagi negara-negara mayoritas muslim, fenomena mempopulerkan penggunaan dinar dan dirham sebagai alat tukar pembayaran dan kegiatan transaksi ekonomi dilandasi oleh beberapa hal berikut: ${ }^{6}$

Pertama, dalam Alquran dan al-Sunnah banyak menyebutkan harta dan kekayaan dengan istilah emas dan perak (dinar dan dirham). Keyakinan ini semakin mendorong penggunaan atas keduanya meski tidak ada keharusan. Dalam sejarah Islam, terdapat dua kelompok yang mendefinisikan uang. Kelompok pertama adalah yang membatasi uang hanya pada emas dan perak saja, diantaranya Mujahid, AbuHanifah, An-Nakha'i, Abu Yusuf, An-Nabhani dan Baqir Sadr. Sedang yang tidak membatasi uang hanya pada emas dan perak saja adalah Laith ibn Sa' ad, Ibnu Taymiyah, As-Syaibani, Ibn Hazm, dan AzZuhri.

Kedua adalah dalam upaya menegakkan rukun Islam yaitu membayar zakat dan menegakkan hukum Islam yaitu hukuman bagi pencuri yang ukuran standarnya adalah dinar dan dirham. Seorang muslim yang memiliki harta emas, uang dan kekayaan lainnyayang telah mencapai nishob (ukuran berat) senilai emas 20 dinar wajib membayar zakat. Bagi pencuri yang senilai Vs dinar, maka padanya wajib dikenakan hukuman had (potong tangan), meski dalam tatanan implementasi sangat sulit untuk diterapkan.

\footnotetext{
${ }^{3}$ Ibid.

${ }^{4}$ Mursyidi, Uang, Kapitalisme, dan Islam, [online], (tersedia): (http://jurnalekis.blogspot.com, 2011).

${ }^{5}$ Tim Wakala, Dinar Dirham, [online], (tersedia): (http://wakalanusantara.com)

${ }^{6}$ Pujiyono, Arif, Dinar dan Sistem Standar Tunggal Emas, [online], (tersedia): (http://eprints.undip.ac.id/13980/1/).
} 
Ketiga, bahwa uang emas bersifat universal dan dapat diterima oleh setiap manusia karena bahannya adalah emas dan relatif lebih sulit untuk dipalsukan. Uang emas memiliki warna, kadar dan kekuatan tertentu yang tidak bisa dibuat dari bahan logam lain. Berbeda dengan uang kertas yang tidak jarang sulit untuk diterima oleh manusia dannegara lain, apakah alasan politis maupun alasan lain. Pemalsuan terhadap uang kertasjuga lebih mudah untuk dilakukan.

Keempat, uang emas dapat digunakan sebagai alat simpanan yang nilainya relatif stabil. Dengan uang emas, nilainya tidak mengalami fluktuasi yang tajam, kerena nilai uang nominal sama dengan nilai intrinsiknya. Hal ini berbeda dengan uang kertas yang nilainya sangat fluktuatif dan berbeda antara nilai nominal dengan nilai intrinsik uang. Stabilitas uang kertas sebagai alat pembayaran juga tidak terjamin, akibat digunakannya konsep time value of money dan kesalahan dalam memfungsikan uang. Efek samping yang dirasakan dalam aktifitas ekonomi adalah bahwa nilai uang (kertas) akan berubah setiap kurun waktu karena nilainya mengalami penyusutan. Hal inilah yang membuat uang kertas dapat dipergunakan sebagai alat komoditi perdagangan dan spekulasi, bukan sebagai alat tukar pembayaran. Dampak digunakannya uang sebagai komoditi perdagangan adalah kehancuran nilai mata uang yang dijadikan sebagai sarana spekulasi, sehingga menyebabkan nilai mata uang jatuh. Jatuhnya nilai mata uang inilah yang banyak disimpulkan para ekonom sebagai penyebab kehancuran dan krisis ekonomi suatu negara.

Paparan di atas mengisyaratkan bahwa di dalam ekonomi Islam uang yang direkomendasikan adalah emas dan perak atau biasa disebut dengan dinar dan dirham. Dipilihnya mata uang emas dan perak paling tidak karena empat alasan, yaitu Pertama, dalam Al-Quran dan As Sunnah banyak menyebutkan harta dan kekayaan dengan istilah emas dan perak (dinar dan dirham). Keyakinan ini semakin mendorong penggunaan atas keduanya meski tidak ada keharusan. Kedua adalah dalam upaya menegakkan rukun Islam yaitu membayar zakat dan menegakkan hukum Islam yaitu hukuman bagi pencuri yang ukuran standarnya adalah dinar dan dirham. Ketiga, bahwa uang emas bersifat universal dan dapat diterima oleh setiap manusia karena bahannya adalah emas dan relatif lebih sulit untuk dipalsukan. Keempat, uang emas dapat digunakan sebagai alat simpanan yang nilainya relatif stabil.

\section{Fungsi Uang Menurut Islam}

Dalam ekonomi Islam, fungsi uang yang diakui hanya sebagai alat tukar (medium of exchange) dan kesatuan hitung (unit of account). Uang itu sendiri tidak memberikan kegunaan/manfaat, akan tetapi fungsi uanglah yang memberikan kegunaan. Uang menjadi berguna jika ditukar dengan benda yang nyata atau jika digunakan untuk membeli jasa. Oleh karena itu uang tidak bisa menjadi komoditi/barang yang dapat diperdagangkan. ${ }^{7}$ Senada dengan pendapat sebelumnya, Mahbubi Ali menyatakan bahwa dalam Islam uang

\footnotetext{
${ }^{7}$ Muhaimin, Fungsi Uang Dalam Perspektif Ekonomi Islam, [online], (tersedia): http://muhaiminkhair.wordpress.com/2010/04/29).
} 
hanya berfungsi sebagai alat tukar. Jadi uang adalah sesuatu yang terus mengalir dalam perekonomian, atau lebih dikenal sebagai flow concept. Konsep ini berbeda dengan sistem perekonomian kapitalis, di mana uang dipandang tidak saja sebagai alat tukar yang sah (legal tender) melainkan juga dipandang sebagai komoditas. $^{8}$

Menurut al-Ghazali dalam Gamal, uang diibaratkan cermin yang tidak mempunyai warna, tetapi dapat merefleksikan semua warna, yang maksudnya adalah uang tidak mempunyai harga, tetapi merefleksikan harga semua barang, atau dalam istilah ekonomi klasik disebutkan bahwa uang tidak memberikan kegunaan langsung (direct utility function), yang artinya adalah jika uang digunakan untuk membeli barang, maka barang itu yang akan memberikan kegunaan. ${ }^{9}$

Dalam konsep ekonomi Islam uang adalah milik masyarakat (money is public goods). Barang siapa yang menimbun uang atau dibiarkan tidak produktif berarti mengurangi jumlah uang beredar yang dapat mengakibatkan tidak jalannya perekonomian. Jika seseorang sengaja menumpuk uangnya tidak dibelanjakan, sama artinya dengan menghalangi proses atau kelancaran jual beli. Implikasinya proses pertukaran dalam perekonomian terhambat. Di samping itu penumpukan uang/harta juga dapat mendorong manusia cenderung pada sifat-sifat tidak baik seperti tamak, rakus dan malas beramal (zakat, infak dan sadaqah). Sifat-sifat tidak baik ini juga mempunyai imbas yang tidak baik terhadap kelangsungan perekonomian. Oleh karenanya Islam melarang penumpukan / penimbunan harta, memonopoli kekayaan.

Merujuk kepada Al-Quran, al-Ghazali dalam Gamal berpendapat bahwa orang yang menimbun uang adalah seorang penjahat, karena menimbun uang berarti menarik uang sementara dari peredaran.Dalam teori moneter modern, penimbunan uang berarti memperlambat perputaran uang. Hal ini berarti memperkecil terjadinya transaksi, sehingga perekonomian menjadi lesu. Selain itu, al-Ghazali juga menyatakan bahwa mencetak atau mengedarkan uang palsu lebih berbahaya daripada mencuri seribu dirham, karena mencuri adalah suatu perbuatan dosa, sedangkan mencetak dan mengedarkan uang palsu dosanya akan terus berulang setiap kali uang palsu itu dipergunakan dan akan merugikan siapapun yang menerimanya dalam jangka waktu yang lebih panjang. ${ }^{10}$

Berdasarkan beberapa pendapat para ahli di atas, maka dapat dinyatakan bahwa dalam perspektif Islam fungsi uang hanya terbatas pada uang sebagai alat tukar barang dan jasa. Islam melarang penumpukan uang dan menjadikan uang sebagai sebuah komuditas. Dalam teori moneter modern,

\footnotetext{
${ }^{8}$ Ali, Mahbubi, Konsep Uang dalam Islam, [online], (tersedia): (http://jurnalekis.blogspot.com/2010/09)

${ }^{9}$ Gamal, Merza, Fungsi Uang dalam Islam, [online], (tersedia): (http://jacksite.wordpress.com/2007/07/11).

${ }^{10}$ Gamal, Merza, Fungsi Uang dalam Islam, [online], (tersedia): (http://jacksite.wordpress.com/2007/07/11).
} 
penimbunan uang berarti memperlambat perputaran uang. Hal ini berarti memperkecil terjadinya transaksi, sehingga perekonomian menjadi lesu.

\section{Pengharaman Riba dalam Ekonomi Islam}

Variabel yang terkait dengan uang dalam ekonomi Islam adalah riba. Nash-nash syariah telah mengharamkan riba dengan sangat keras. Nash-nash itu bersifat qath'i ats-tsubût (pasti sumbernya) dan qath'i ad-dilâlah (pasti pengertiannya), tidak menyisakan ruang bagi ijtihad atau penakwilan (QS 2: 275-279). ${ }^{11}$ Karena itu, sistem keuangan di negara Khilafah tidak mengenal bank dan lembaga kredit ribawi. Ketiadaan lembaga ribawi ini memiliki tiga dimensi dalam menjamin kehidupan perekonomian yang aman:

Mengarahkan fokus masyarakat pada ekonomi produktif atau sektor riil. Melindungi kaum Muslim dan ahl adz-dzimmah dari kerugian harta mereka karena riba. Tidak akan memunculkan fenomena kebangkrutan, sebagaimana terlihat pada bank-bank kapitalis, dan menyisakan kelompok besar orang yang kehilangan harta mereka atau rekening mereka menguap. Dengan menghalangi sistem riba dan mengharamkannya secara keras dan tegas, Islam telah menutup celah-celah yang memungkinkan masuknya krisis keuangan. Dengan itu kehidupan kaum Muslim akan tetap aman, kokoh dan kuat terhadap krisis.

Selain itu, Islam mendorong kaum Muslim untuk saling memberi utang di antara mereka. Lebih dari itu, di antara tugas berbagai institusi (direktorat) di negara Khilafah adalah menyediakan kredit tanpa riba dalam sektor pertanian, perdagangan dan industri, dalam kerangka program negara untuk mengembangkan perekonomian dan menjalankan berbagai kebijakannya untuk memerangi kemiskinan dengan menciptakan lapangan kerja dan menjamin produksi barang.

\section{Pandangan Islam Terhadap Bursa}

Pasar modal dan bursa berjangka komoditas dalam sistem Kapitalisme berperan penting seperti riba dalam mengkonsentrasikan kekayaan pada tangan segelintir orang. Lebih dari itu, bursa juga menghalangi sirkulasi harta di sektor riil, dan mengubahnya menjadi per-ekonomian angka dan kertas (ekonomi non-riil).

Dalam ekonomi Islam, sektor finansial mengikuti atau terikat dengan sektor riil. Dalam pandangan Islam, uang bukan komoditas (barang dagangan), melainkan alat pembayaran. Islam menolak keras segala jenis transaksi semu seperti yang terjadi di pasar uang atau pasar modal saat ini. Sebaliknya, Islam mendorong perdagangan internasional. Nabi Muhammad SAW., sebelum menjadi rasul, telah menjadi pedagang internasional sejak usia remaja. Ketika berusia belasan tahun, beliau telah berdagang ke Syam (Suriah), Yaman dan beberapa negara di kawasan Teluk sekarang. Lalu saat beliau menjadi rasul sekaligus menjadi kepala negara Daulah Islamiyah di Madinah, sejak awal kekuasaannya, umat Islam telah menjalin kontak bisnis dengan Cina, India,

\footnotetext{
${ }^{11}$ Alqur'an (2012). Alqur'an dan Terjemahannya. Jakarta: Madinatul Ilmi.
} 
Persia, dan Romawi. Bahkan hanya dua abad kemudian (abad kedelapan), para pedagang Islam telah mencapai Eropa Utara.

Sepanjang keberadaan Daulah Islamiyah pada zaman Nabi Muhammad SAW. jarang sekali terjadi krisis ekonomi (Pernah sekali Daulah Islam mengalami defisit, yaitu sebelum Perang Hunain, namun segera dilunasi setelah perang). Pada zaman Kekhilafahan Islam, khususnya masa Khulafaur Rasyidin juga begitu. Pada zaman Khalifah Umar bin al-Khaththab dan khalifah Utsman bin Affan APBN malah sering mengalami surplus. ${ }^{12}$

Dalam pandangan Islam, pasar jual beli harus diatur dengan hukum syariah yang menjamin tidak adanya konflik dan tidak adanya aktivitas memakan harta dengan jalan yang batil. Di antara hukum-hukum itu adalah: ${ }^{13}$

Pertama, Melarang penjualan barang yang belum dimiliki oleh penjual dan belum berada di bawah kuasanya seperti yang terjadi dalam bursa berjangka komoditas.

Kedua, Melarang tanâjusy atau spekulasi, yaitu menaikkan tawaran bukan untuk membeli, tetapi hanya untuk menaikkan harga jual.

Ketiga, Melarang jual-beli enam jenis komoditas ribawi (emas dan perak [termasuk uang], gandum, jewawut, kurma, dan garam) tanpa serahterima secara langsung dalam jual-beli antar jenis yang berbeda; dan tanpa serah-terima langsung dan kesamaan jumlah dalam jual pada jenis yang sama.

Keempat, Melarang sirkulasi saham karena perseroan terbatas (PT) dan sahamnya adalah batil (tidak sah). Saham itu merupakan surat berharga yang mengandung campuran antara sejumlah modal yang halal dan keuntungan yang haram, dalam satu akad yang batil dan muamalah yang batil, tanpa bisa dibedakan antara harta yang halal dan yang haram. Syariah Islam juga melarang sirkulasi dan jual-beli obligasi (bonds). Sebab, obligasi merupakan surat utang yang diinvestasikan dengan riba. Apalagi ada keharaman jual-beli utang dengan utang. Sirkulasi dan jual beli seluruh surat berharga ribawi juga dilarang.

\section{Penutup}

Akhirnya, berdasarkan paparan di atas dapat ditarik beberapa kesimpulan sebagaimana diuraikan di bawah ini :

Pertama, Secara teoretis, mata uang yang digunakan dalam Ekonomi Islam adalah dinar (Emas) dan dirham (Perak). Dinar emas adalah koin emas berkadar 22 karat $(91,70 \%)$ dengan berat 4,25 gram. Sedangkan Dirham perak adalah koin perak murni (99.95\%) dengan berat 2.975 gram.

Kedua, Mata uang emas dan perak dianggap mata uang terbaik paling tidak karena empat alasan, yaitu Pertama, dalam Al-Quran dan As Sunnah banyak menyebutkan harta dan kekayaan dengan istilah emas dan perak (dinar dan dirham). Kedua adalah dalam upaya menegakkan rukun Islam yaitu membayar zakat dan menegakkan hukum Islam yaitu hukuman bagi pencuri

\footnotetext{
${ }^{12}$ Idham Sirunna. (2008). Saatnya Sistem Ekonomi Islam menggantikan Sistem Ekonomi Kapitalisme. . [Online]. (Tersedia): (http://idhams.wordpress.com).

${ }^{13}$ Abdurrahman, Sistem Ekonomi Islam Satu-satunya Harapan, [online], (tersedia): (http://hizbut-tahrir.or.id/2009/01/30).
} 
yang ukuran standarnya adalah dinar dan dirham. Ketiga, bahwa uang emas bersifat universal dan dapat diterima oleh setiap manusia karena bahannya adalah emas dan relatif lebih sulit untuk dipalsukan. Keempat, uang emas dapat digunakan sebagai alat simpanan yang nilainyarelatif stabil.

Ketiga, Fungsi uang dalam perspektif Ekonomi Islam hanya terbatas pada uang sebagai alat tukar barang dan jasa. Islam melarang penumpukan uang dan menjadikan uang sebagai sebuah komuditas. Karena penimbunan uang berarti memperlambat perputaran uang. Hal ini berarti memperkecil terjadinya transaksi, sehingga perekonomian menjadi lesu.

Keempat, Islam mengharamkan riba dan menolak segala jenis transaksi semu seperti yang terjadi di pasar uang atau pasar modal saat ini. Sebaliknya, Islam mendorong perdagangan internasional.

\section{Pustaka Acuan}

Abdurrahman. (2009). Sistem Ekonomi Islam Satu-satunya Harapan.[online]. (tersedia): (http://hizbut-tahrir.or.id).

Ali, Mahbubi. (2010). Konsep Uang dalam Islam.[online], (tersedia): (http://jurnalekis.blogspot.com).

Gamal, Merza. (2007). Fungsi Uang dalam Islam, [online], (tersedia): (http://jacksite.wordpress.com).

Idham Sirunna. (2008). Saatnya Sistem Ekonomi Islam menggantikan Sistem Ekonomi Kapitalisme. . [Online]. (Tersedia): (http://idhams.wordpress.com).

Muhaimin. (2010). Fungsi Uang Dalam Perspektif Ekonomi Islam.[online].(tersedia): (http://muhaiminkhair.wordpress.com)

Mursyidi. (2011). Uang, Kapitalisme, dan Islam. [online]. (tersedia): (http://jurnalekis.blogspot.com).

Pujiyono, Arif. (2014). Dinar dan Sistem Standar Tunggal Emas, [online].(tersedia): (http://eprints.undip.ac.id/13980/1/).

Tim Wakala. (2014). Dinar Dirham.[online]. (http://wakalanusantara.com). Wikipedia. (2014). Uang. [online]. (tersedia): (http://id.wikipedia.org). 